\title{
Implementasi Metode Simple Multi Attributerating Technique (SMART) dalam Keputusan Pemilihan Model Pembelajaran di Masa Pandemi Covid-19 Implementation of the Simple Multi Attributerating Technique (SMART) Method in Election Decisions Learning Models during the Covid-19 Pandemic
}

Jakaria Sembiring ${ }^{1}$, Ambiyar $^{2}$, Unung Verawardina ${ }^{3}$

${ }^{1}$ Program Studi Manajemen Informatika, Politeknik Unggul LP3M

${ }^{2}$ Fakultas Teknik, Universitas Negeri Padang

${ }^{3}$ Fakultas Pendidikan MIPATEK, IKIP PGRI Pontianak

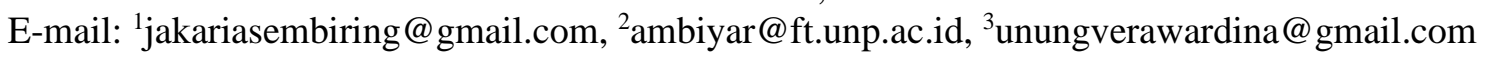

\begin{abstract}
Abstrak
Penelitian bertujuan memilih model pembelajaran yang tepat pada masa pandemi Covid-19. Covid-19 menyebabkan seluruh aktivitas dilakukan dari rumah. Selama ini pembelajaran dilakukan tatap muka. Manajemen Politeknik panik dan bingung, model pembelajaran apa yang dapat dipergunakan untuk pelaksanaan pembelajaran dari rumah. Manajemen memiliki target untuk setiap aktivitas pembelajaran. Berdasarkan parameter tersebut manajemen Politeknik membuat kriteria baru untuk memilih model pembelajaran yang tepat. Adapun kriteria baru yang dibuat antara lain mudah disampaikan via teknologi, maksimal meski tidak tatap muka, memiliki prosedur operasional situasional, tujuan tetap terpenuhi meski dari rumah, konteks belajar nyaman, rasional secara praktik dan teori, kemudian memungkinkan individu dan kolaborasi. Konteks sistem pendukung keputusan dapat dijadikan solusi untuk menyelesaikan permasalahan. Metode Simple Multi Attributerating Technique (SMART) yang mampu memilih alternatif yang tepat berdasarkan target yang telah ditetapkan dapat dijadikan sebagai metode. Berdasarkan hasil pengujian didapatkan Kesesuaiaan Kegunaan 82,90\% (Layak), Kemudahan Penggunaan 80,15\% (Layak), Mudah dipelajari 81,21\% (Layak), dan Kepuasan Menggunakan $82,40 \%$ (Layak).
\end{abstract}

Kata kunci: Model Pembelajaran, Pandemi Covid-19, SPK, Metode Smart

\begin{abstract}
The research aims to choose a suitable learning model during the Covid-19 pandemic. Covid19 causes all activities to be carried out from home. So far, learning has been done face-to-face. Polytechnic management is panicked and confused about what learning models can be used to implement learning activities from home. Management has a target for each learning activity. Based on these parameters, the Polytechnic management creates new criteria for choosing the suitable learning model to remain within the corridor of standard assessments. The new criteria are, among others, easily conveyed via technology, maximally even though not face to face, have situational operational procedures, objectives are still fulfilled even from home, the learning context is comfortable, practical and theoretical, then allows individuals and collaboration. The context of the decision support system can be used as a solution to solve the problem. The Simple Multi Attributerating Technique (SMART) method, which can choose the correct alternative based on predetermined targets, can be used. Based on the test results, it was found that $82.90 \%$ (feasible), $80.15 \%$ ease of use (feasible), $81.21 \%$ easy to learn (feasible), and $82.40 \%$ satisfaction use (feasible).
\end{abstract}

Keywords: Learning Models, Covid-19 Pandemic, SPK, Smart Method 


\section{PENDAHULUAN}

Senin, 2 Maret 2020 menjadi tanggal bersejarah di Indonesia. Pada tanggal tersebut Presiden Joko Widodo mengumumkan kasus pertama yang terpapar Covid-19 di Indonesia. Setelah itu setiap hari kasus positif terpapar Covid-19 terus ditemukan. Jumlah yang terpapar terus meningkat. Situasi ini menyebabkan pemerintah mengumumkan bahwa seluruh aktivitas untuk sementara dilakukan dari rumah. Bekerja dari rumah, belajar dari rumah, dan beribadah juga dari rumah. Terkhusus untuk belajar dari rumah menjadi dilema tersendiri. Selama ini kegiatan pembelajaran dilakukan secara tatap muka [1]. Tak hanya peserta didik yang merasa bingung, tenaga pengajar juga turut kelimpungan. Disebabkan karena kebiasaan pembelajaran yang berjalan selama ini. Tenaga pengajar belum siap menghadapi kondisi diluar zona nyaman yang secara rutin mereka lakukan [2].

Situasi dan kondisi seperti ini penulis rasakan langsung. Tak hanya penulis, rekan sejawat penulis sesama tenaga pengajar juga merasa kebingungan. Manajemen Politeknik tempat penulis dan sejawat penulis mengajar juga tak kalah panik. Manajemen bingung formula atau model pembelajaran apa yang dapat dipergunakan untuk pelaksanaan aktivitas pembelajaran dari rumah. Sementara manajemen sendiri memiliki target pembelajaran untuk setiap aktivitas pembelajaran yang berjalan [3]. Unit Penjaminan Mutu institusi setiap akhir semester akan melakukan evaluasi melalui angket dan lembar monitoring untuk melihat tingkat ketercapaian pembelajaran. Adapun yang menjadi parameter dari penilaian Unit Penjaminan Mutu antara lain tingkat pemahaman peserta didik, pola mengajar, penguasaan kelas, kemampuan peserta didik menjawab ujian, kesesuaian materi dengan SAP, dan tingkat kehadiran pengajar serta peserta didik. Berdasarkan parameter ini, manajemen Politeknik membuat kriteria baru untuk memilih model pembelajaran yang tepat agar tetap berada dalam koridor penilaian standar Unit Penjaminan Mutu.

Adapun kriteria baru yang dibuat antara lain mudah disampaikan via teknologi, maksimal meski tidak tatap muka, memiliki prosedur operasional situasional, tujuan tetap terpenuhi meski dari rumah, konteks belajar nyaman, rasional secara praktik dan teori, kemudian memungkinkan individu dan kolaborasi. Kriteria pemilihan model pembelajaran ini disesuaikan dengan instruksi belajar dari rumah karena situasi penyebaran Covid-19 yang sangat cepat. Model pembelajaran yang jumlahnya tidak sedikit tentu menjadi permasalahan. Sementara waktu sangat singkat untuk memilih satu dari sekian banyak model pembelajaran yang ada. Sangat baik jika ada sistem yang dapat dipergunakan untuk melakukan pemilihan model pembelajaran sesuai dengan kriteria yang telah ditetapkan. Konteks sistem pendukung keputusan dapat dijadikan solusi untuk menyelesaikan permasalahan [4]. Metode Simple Multi Attributerating Technique (SMART) yang mampu memilih alternatif yang tepat berdasarkan target yang telah ditetapkan dapat dijadikan sebagai metode [5] .

Gumilar Ramadhan Pangaribuan, Agus Perdana Windarto, Wida Prima Mustika, dan Anjar Wanto dalam penelitiannya menggunakan metode SMART dalam pemilihan jenis sapi bagi para peternak sapi potong [6]. Penelitian yang mereka lakukan menghasilkan sapi jenis apa yang layak untuk dijadikan komoditas ternak oleh para peternak sapi potong. Penelitian menjadikan 6 jenis sapi sebagai alternatif dan terdapat 5 kriteria penilaian.

Penelitian dengan menggunakan metode SMART juga dilakukan Tisa Magrisa, Kartina Diah Kusuma Wardhani, dan Maksum Ro'is Adin Saf. Metode SMART dipergunakan untuk memilih kegiatan ekstrakurikuler yang tepat untuk siswa SMA [7]. Mereka menjadikan metode SMART sebagai solusi untuk memilih ekstrakurikuler sesuai dengan potensi dan minat siswa. Jadi siswa tidak memilih ekstrakurikuler yang tidak tepat, namun memilih yang sesuai dengan potensi dirinya. Penelitian ini menegaskan bahwa metode SMART tepat sebagai metode untuk memilih kegiatan ekstrakurikuler.

Pemilihan Karyawan Teladan dengan metode SMART merupakan penelitian Suryanto dan Muhammad Safrizal [8]. Kriteria penelitian antara lain data keahlian, disiplin, kepribadian, kerja team, komunikasi, penampilan, sikap, motivasi kerja, ketelitian dan friendly. Untuk mendukung penelitiannya, mereka membangun aplikasi dengan bahasa pemrograman PHP dan 
database MySQL. Mereka menyatakan dalam penelitiannya bahwa metode SMART mampu dengan tepat dan cepat memilih karyawan teladan. Dengan penelitian ini perusahaan dapat dengan cepat untuk memilih siapa yang layak untuk dipilih sebagai karyawan teladan.

I Made Ari Santosa dalam penelitiannya menggunakan metode SMART untuk pemilihan sekolah PAUD [9]. Tujuannya untuk membantu orang tua dalam memilih sekolah PAUD yang tepat bagi anaknya. Kriteria dalam penelitian ini kurikulum, fasilitas, hingga jarak. Untuk memaksimalkan kinerja, I Made Ari Santosa juga membangun aplikasi. Aplikasi dibangun dengan terlebih dahulu membuat perancangan dengan komponen yang ada. Dalam kesimpulannya dikatakan bahwa metode SMART dapat menyelesaikan permasalahan secara akurat.

Penelitian yang dilakukan dapat dikatakan merupakan langkah pengembangan dengan bentuk berbeda dari penelitian yang sebelumnya. Adapun tujuan dari penelitian ini untuk mengimplementasikan metode Simple Multi Attributerating Technique (SMART) dalam Keputusan Pemilihan Model Pembelajaran di Masa Pandemi Covid-19. Adapun yang menjadi kriteria dalam penelitian ini Mudah disampaikan Via Teknologi, Maksimal meski Tidak Tatap Muka, Memiliki Prosedur Operasional Situasional, Tujuan tetap terpenuhi meski dari rumah, Konteks belajar nyaman, Rasional secara praktik dan teori, dan memungkinkan individu dan kolaborasi. Untuk memaksimalkan dan memudahkan kinerja manajemen dalam menentukan pilihan, dibangun sistem informasi website dengan bahasa pemrograman web dan database berbasis server [10].

\section{METODE PENELITIAN}

Penelitian tentu dilakukan dengan tahapan-tahapan. Dimana masing-masing tahapan memiliki proses demi terwujudnya hasil penelitian yang baik. Adapun tahapan metode penelitian yang dilakukan seperti gambar 1 berikut [11] :

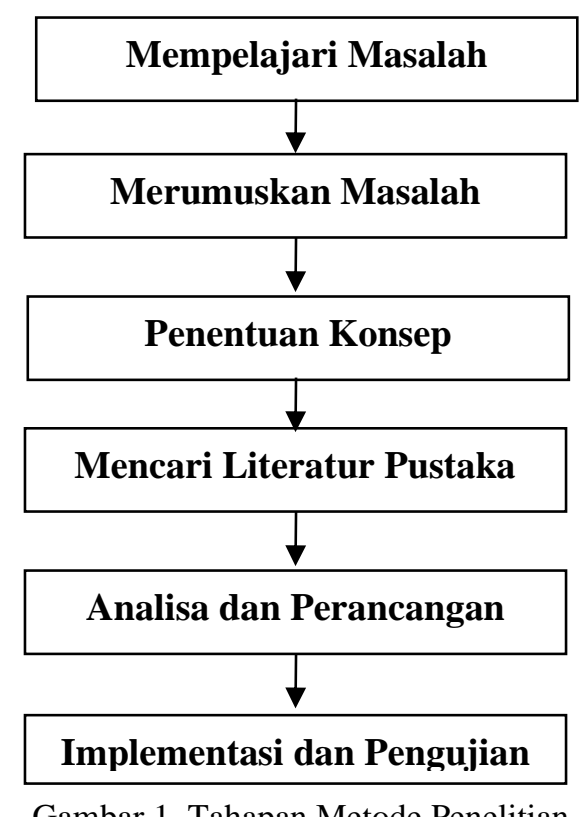

a. Mempelajari Masalah

Mempelajari masalah merupakan langkah awal dalam melakukan penelitian. Masalah dipelajari terlebih dahulu melalui pengamatan dan pengalaman langsung. Selain itu melalui proses diskusi dengan sejawat sesama tenaga pengajar. Kemudian dilanjutkan dengan wawacara dengan manajemen Politeknik tempat penulis mengabdi. 
b. Merumuskan Masalah

Setelah masalah selesai dipelajari, selanjutkan permasalahan yang ditemukan kemudian dirumuskan. Dirumuskan secara berurutan sehingga solusi untuk permasalahan yang ada dapat lebih tepat. Tak hanya itu, dengan merumuskan masalah, penelitian akan berjalan lebih fokus.

c. Penentuan Konsep

Setelah merumuskan masalah, tahapan selanjutnya yaitu menentukan konsep. Menentukan konsep maksudnya memilih metode apa yang tepat dipergunakan sebagai solusi penyelesaian. Dalam hal ini yang dipilih metode yaitu Simple Multi Attributerating Technique (SMART).

\section{d. Mencari Literatur Pustaka}

Literatur pustaka dicari untuk mendukung maksimalnya hasil penelitian. Adapun literatur pustaka yang dipergunakan berasal dari publikasi jurnal maupun prosiding. Tak hanya itu, buku juga dijadikan sebagai bahan acuan untuk mempertegas pelaksanaan penelitian. Seluruh literatur pustaka berhubungan dengan metode yaitu Simple Multi Attributerating Technique (SMART).

\section{e. Analisa dan Perancangan}

Analisa dan Perancangan merupakan tahapan untuk penyelesaian pendukung keputusan dengan metode Simple Multi Attributerating Technique (SMART). Tahapan analisa, peneliti melakukan penyelesaian sesuai dengan langkah-langkah penyelesaian dengan metode Simple Multi Attributerating Technique (SMART). Perancangan dilakukan sebagai tahapan dalam membangun sistem untuk mendukung penyelesaian dengan metode Simple Multi Attributerating Technique (SMART) [12] .

i. Analisa

Adapun bentuk analisa sebagai berikut :

1. Menentukan Kriteria dan Bobot

Kriteria dan bobot merupakan parameter yang akan dijadikan sebagai acuan dalam melakukan penilaian terhadap model pembelajaran yang akan dijadikan sebagai alternatif. Adapun kriteria dan bobot seperti pada tabel 1:

Tabel 1 Kriteria dan Bobot

\begin{tabular}{|l|l|}
\hline \multicolumn{1}{|c|}{ Kriteria } & Bobot (\%) \\
\hline Mudah disampaikan Via Teknologi & 20 \\
\hline Maksimal meski Tidak Tatap Muka & 20 \\
\hline Memiliki Prosedur Operasional Situasional & 10 \\
\hline Tujuan tetap terpenuhi meski dari rumah & 10 \\
\hline Konteks belajar nyaman & 10 \\
\hline Rasional secara praktik dan teori & 15 \\
\hline Memungkinkan individu dan kolaborasi & 15 \\
\hline
\end{tabular}

2. Membuat Alternatif

Alternatif merupakan model-model pembelajaran yang akan diuji kesesuaiannya dengan kriteria dan bobot yang telah ditentukan. Berikut alternatif di tabel 2 :

Tabel 2 Alternatif

\begin{tabular}{|l|l|}
\hline No & \multicolumn{1}{c|}{ Nama Alternatif } \\
\hline 1 & Flipped Classroom \\
\hline 2 & Discovery Learning \\
\hline 3 & Debat \\
\hline 4 & Play Role \\
\hline 5 & E-Learning \\
\hline 6 & Problem Based Learning \\
\hline
\end{tabular}




\begin{tabular}{|l|l|}
\hline 7 & Inquiry Learning \\
\hline 8 & Project Based Learning \\
\hline 9 & Action Learning \\
\hline 10 & BYOD \\
\hline
\end{tabular}

3. Parameter

Parameter merupakan nilai yang akan dicapai oleh alternatif yang telah ditetapkan, sesuai dengan kriteria dan bobot yang ada. Adapun parameter yang ditetapkan seperti pada tabel 3 :

Tabel 3 Parameter

\begin{tabular}{|l|l|}
\hline \multicolumn{1}{|c|}{ Parameter } & \\
\hline Sangat Baik & 10 \\
\hline Baik & 8 \\
\hline Cukup & 6 \\
\hline Kurang & 4 \\
\hline Sangat Kurang & 2 \\
\hline
\end{tabular}

Setelah menentukan kriteria, bobot, alternatif, dan parameter, berikutnya melakukan penyelesaian sesuai dengan langkah-langkah penyelesaian menggunakan metode Simple Multi Attributerating Technique (SMART). Adapun rumus penyelesaiannya [13] :

$$
u\left(a_{i}\right)=\sum_{J=1}^{m} w_{j} u_{i}\left(a_{i}\right), \quad i=1,2, \ldots m
$$

Petunjuk :

$w_{j}=$ Hasil proses bobot kriteria ke-j dan $k$ kriteria

$u\left(a_{i}\right)=$ Hasil utility kriteria ke-i kepada kriteria ke-i

ii. Perancangan

Perancangan merupakan tahapan untuk membangun sistem yang akan mendukung proses penyelesaian masalah dengan metode Simple Multi Attributerating Technique (SMART). Adapun urutan perancangan yang menjadi parameter pembuatan sistem sesuai urutan penggunaan sistem nantinya sebagai berikut :

1. Rancangan Tampak Awal Program di Jalankan

Rancangan awal merupakan tampilan awal ketika sistem dijalankan. Pengguna diharuskan untuk mengisi user name dan password. Adapun tampilan awal seperti pada gambar 2 berikut :

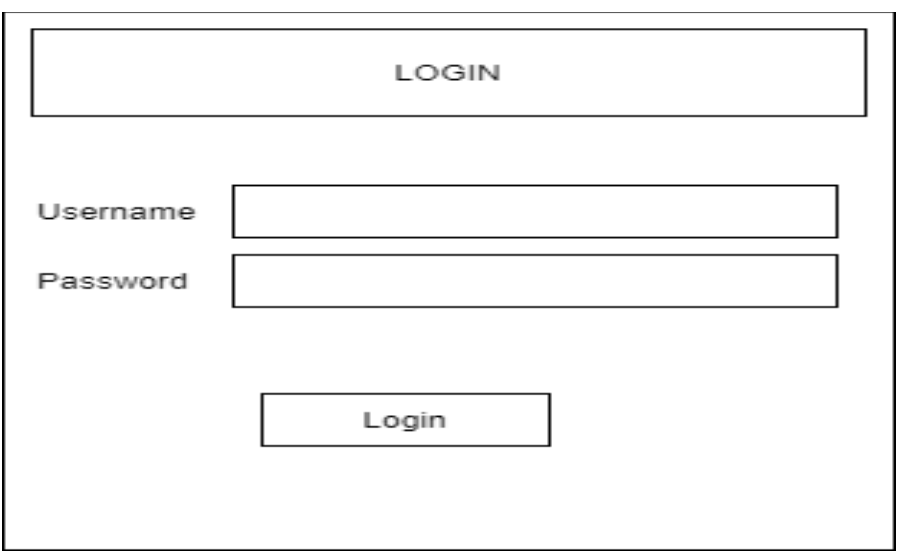

Gambar 2. Rancangan Tampak Awal Program di Jalankan 
2. Rancangan Tampak Setelah Login dilakukan

Setelah user name dan password diisikan dan sistem mengenali user name dan password tersebut, selanjutnya akan tampil menu sistem yang telah dibangun seperti pada gambar 3 berikut :

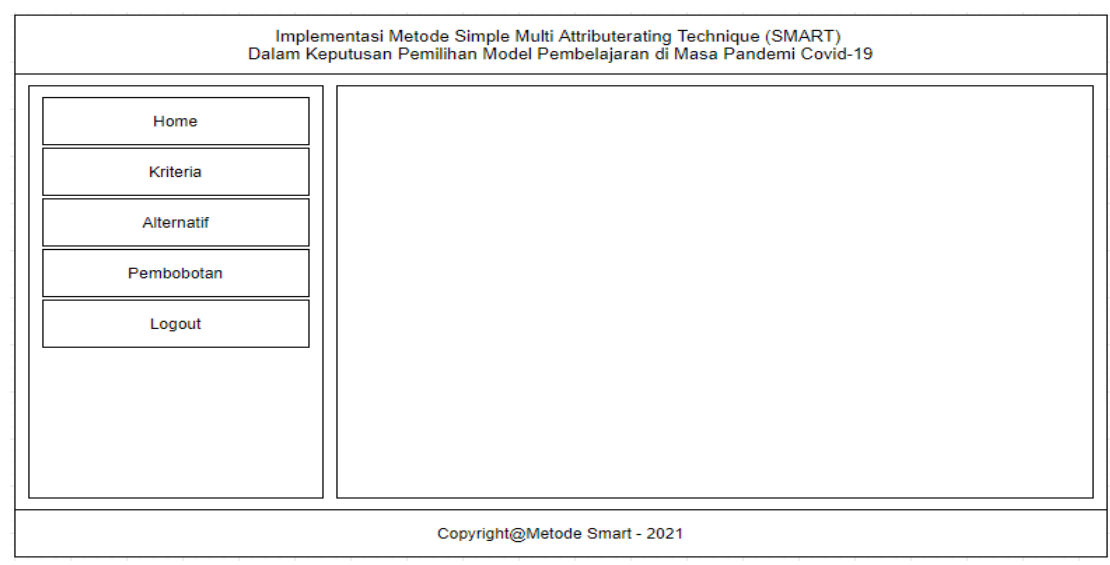

Gambar 3. Rancangan Tampak Setelah Login dilakukan

3. Rancangan Tampak Kriteria

Berikutnya akan tampil pilihan-pilihan sesuai dengan langkah-langkah penyelesaian dengan metode SMART. Seperti pada gambar 4 dibawah :

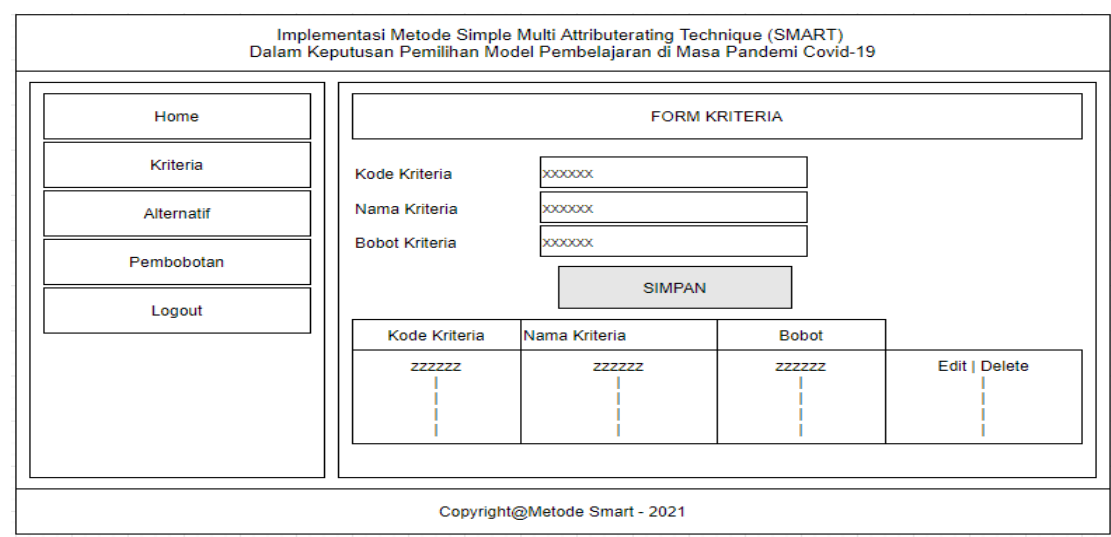

Gambar 4. Rancangan Halaman Kriteria

4. Rancangan Halaman Alternatif

Halaman menu alternatif berfungsi untuk menambahkan, mengubah, dan menghapus alternatif yang telah ditentukan. Seperti pada gambar 5 berikut :

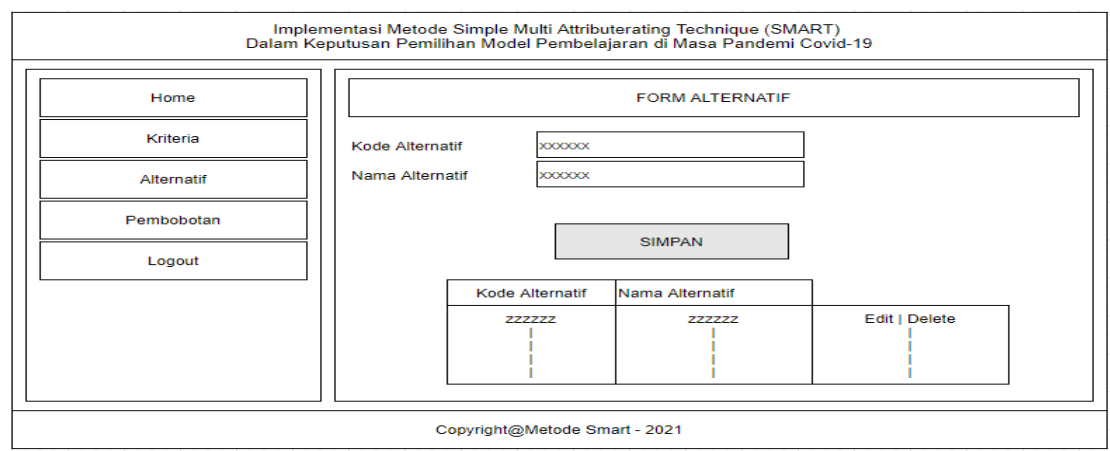

Gambar 5. Rancangan Halaman Alternatif 
f. Implementasi dan Pengujian

Implementasi dan Pengujian merupakan tahapan akhir dari penelitian yang dilakukan. Implementasi dilakukan dengan menjalankan sistem yang dibangun untuk menyelesaikan permasalahan dengan metode Simple Multi Attributerating Technique (SMART). Adapun sistem dibangun dengan bahasa pemrograman berbasis web yakni PHP dan MySQL sebagai database. Untuk pengujian yakni melakukan tahapan-tahapan menginputkan kriteria, bobot, alternatif, dan parameter untuk kemudian dilakukan perangkingan guna mendapatkan model pembelajaran apa yang paling tepat dimanfaatkan di masa pandemi Covid-19.

\section{HASIL DAN PEMBAHASAN}

\subsection{Hasil dan Implementasi}

Diawali dengan membuat acuan perhitungan yang dijadikan dasar dalam membangun sistem untuk penyelesaian dengan metode Simple Multi Attributerating Technique (SMART). Adapun acuan yang dijadikan dasar sebagai berikut :

1. Kriteria yang Digunakan

Tabel 4 Kriteria

\begin{tabular}{|c|l|c|}
\hline No. & \multicolumn{1}{|c|}{ Kriteria } & Bobot $\mathbf{W}_{\mathbf{j}}$ \\
\hline 1. & Mudah disampaikan Via Teknologi & $20 \%$ \\
\hline 2. & Maksimal meski Tidak Tatap Muka & $40 \%$ \\
\hline 3. & Memiliki Prosedur Operasional Situasional & $40 \%$ \\
\hline
\end{tabular}

2. Berdasarkan rumus normalisasi, nilai bobot $\mathrm{W}_{\mathrm{j}}$ setiap kriteria dibagi total bobot kriteria. diperoleh hasil.

Tabel 5 Normalisasi

\begin{tabular}{|c|l|c|c|}
\hline No. & \multicolumn{1}{|c|}{ Kriteria } & Bobot $\mathbf{W}_{\mathbf{j}}$ & Normalisasi \\
\hline 1. & Mudah disampaikan Via Teknologi & $20 \%$ & 0.2 \\
\hline 2. & Maksimal meski Tidak Tatap Muka & $40 \%$ & 0.4 \\
\hline 3. & Memiliki Prosedur Operasional Situasional & $40 \%$ & 0.4 \\
\hline
\end{tabular}

3. Memberikan nilai kriteria pada setiap alternatif, sebagai acuan hanya digunakan dua alternatif.

Tabel 6 Nilai Alternatif 1

\begin{tabular}{|c|l|c|}
\hline No. & \multicolumn{1}{|c|}{ Kriteria } & Nilai \\
\hline 1. & Mudah disampaikan Via Teknologi & 75 \\
\hline 2. & Maksimal meski Tidak Tatap Muka & 100 \\
\hline 3. & Memiliki Prosedur Operasional Situasional & 75 \\
\hline
\end{tabular}

Tabel 7 Nilai Alternatif 2

\begin{tabular}{|c|l|c|}
\hline No. & \multicolumn{1}{|c|}{ Kriteria } & Nilai \\
\hline 1. & Mudah disampaikan Via Teknologi & 100 \\
\hline 2. & Maksimal meski Tidak Tatap Muka & 75 \\
\hline 3. & Memiliki Prosedur Operasional Situasional & 75 \\
\hline
\end{tabular}


4. Hitung utility kriteria sebagai berikut :

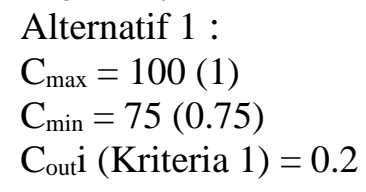

\section{Maka}

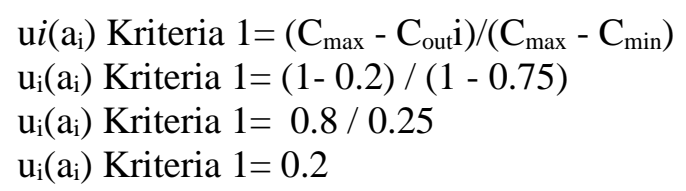

Diperoleh hasil :

Tabel 8 Hasil Nilai Akhir Alternatif 1

\begin{tabular}{|c|l|c|c|c|c|c|}
\hline No. & \multicolumn{1}{|c|}{ Kriteria } & Nilai & Bobot $\mathbf{W}_{\mathbf{j}}$ & $\mathbf{C}_{\max }-\mathbf{C}_{\text {out }} \mathbf{i}(\mathbf{a})$ & $\mathbf{C}_{\max }-\mathbf{C}_{\text {out }} \mathbf{i}(\mathbf{b})$ & $\mathbf{a} / \mathbf{b}$ \\
\hline 1. & $\begin{array}{l}\text { Mudah disampaikan Via } \\
\text { Teknologi }\end{array}$ & 0.75 & 0.2 & 0.8 & 0.25 & 3.2 \\
\hline 2. & $\begin{array}{l}\text { Maksimal meski Tidak } \\
\text { Tatap Muka }\end{array}$ & 1 & 0.4 & 0.6 & 0.25 & 2.4 \\
\hline 3. & $\begin{array}{l}\text { Memiliki Prosedur } \\
\text { Operasional Situasional }\end{array}$ & 0.75 & 0.4 & 0.6 & 0.25 & 2.4 \\
\hline \multicolumn{4}{|c|}{ Hasil Akhir Alternatif 1 : } & $\mathbf{8}$ \\
\hline
\end{tabular}

Tabel 9 Hasil Nilai Akhir Alternatif 2

\begin{tabular}{|c|l|c|c|c|c|c|}
\hline No. & \multicolumn{1}{|c|}{ Kriteria } & Nilai & Bobot $\mathbf{W}_{\mathbf{j}}$ & $\mathbf{C}_{\mathbf{m a x}}-\mathbf{C}_{\text {out }} \mathbf{i}(\mathbf{a})$ & $\mathbf{C}_{\mathbf{m a x}}-\mathbf{C}_{\text {out }} \mathbf{i}(\mathbf{b})$ & $\mathbf{a} / \mathbf{b}$ \\
\hline 1. & $\begin{array}{l}\text { Mudah disampaikan Via } \\
\text { Teknologi }\end{array}$ & 1 & 0.2 & 0.8 & 0.26 & 3.1 \\
\hline 2. & $\begin{array}{l}\text { Maksimal meski Tidak } \\
\text { Tatap Muka }\end{array}$ & 0.75 & 0.4 & 0.6 & 0.26 & 2.3 \\
\hline 3. & $\begin{array}{l}\text { Memiliki Prosedur } \\
\text { Operasional Situasional }\end{array}$ & 0.74 & 0.4 & 0.6 & 0.26 & 2.3 \\
\hline \multicolumn{7}{|r|}{} \\
\hline
\end{tabular}

Hasil yang diperoleh kemudian diubah kedalam bentuk persentase maka : Alternatif $1=$ $80 \%$ dan Alternatif $2=77 \%$. Dengan demikian alternatif 1 nilainya lebih tinggi dari alternatif 2 dan dapat dijadikan sebagai pilihan sesuai dengan permasalahan yang akan diselesaikan.

Sistem yang dibangun memiliki tampilan-tampilan sesuai dengan urutan yang ada. Berikut tampilan sistem yang dibangun :

1. Tampilan Menu Awal

Pada tampilan menu awal, pengguna sistem harus memasukkan user name dan password agar dapat menggunakan sistem. Setelah mengisikan user name dan password, pengguna dapat menekan tombol login untuk masuk kedalam menu utama dari sistem yang dibangun. Adapun bentuk tampilan menu awal seperti gambar 6 sebagai berikut : 


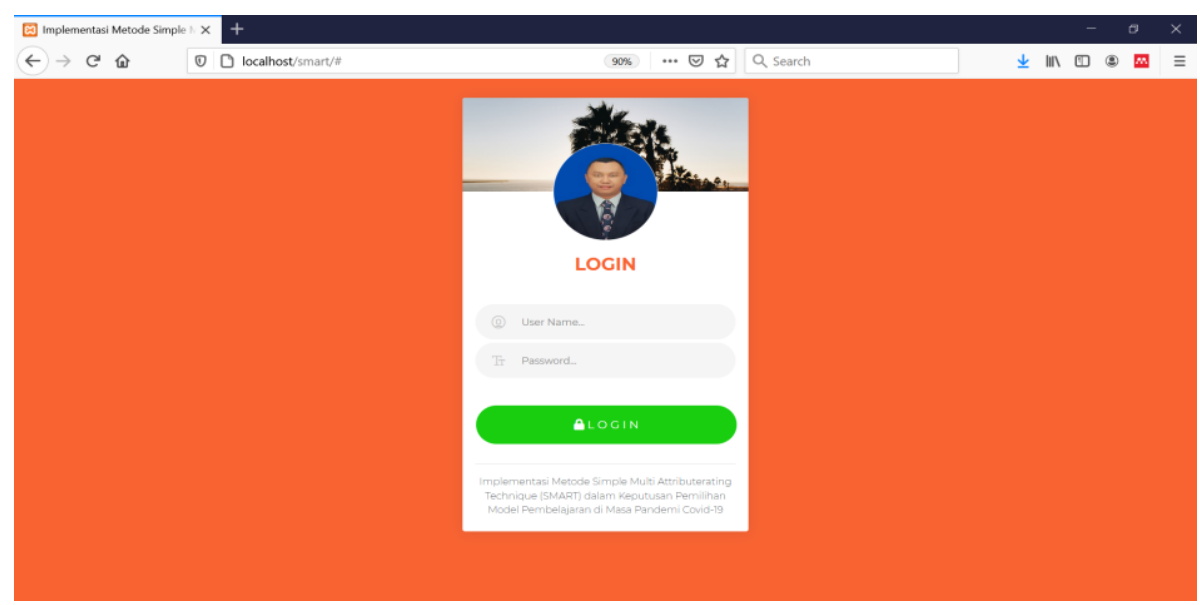

Gambar 6. Tampilan Menu Awal

2. Tampilan Menu Utama

Tampilan Menu Utama menampilkan menu-menu sesuai dengan urutan sistem. Adapun bentuk tampilan menu utama seperti gambar 7 sebagai berikut :

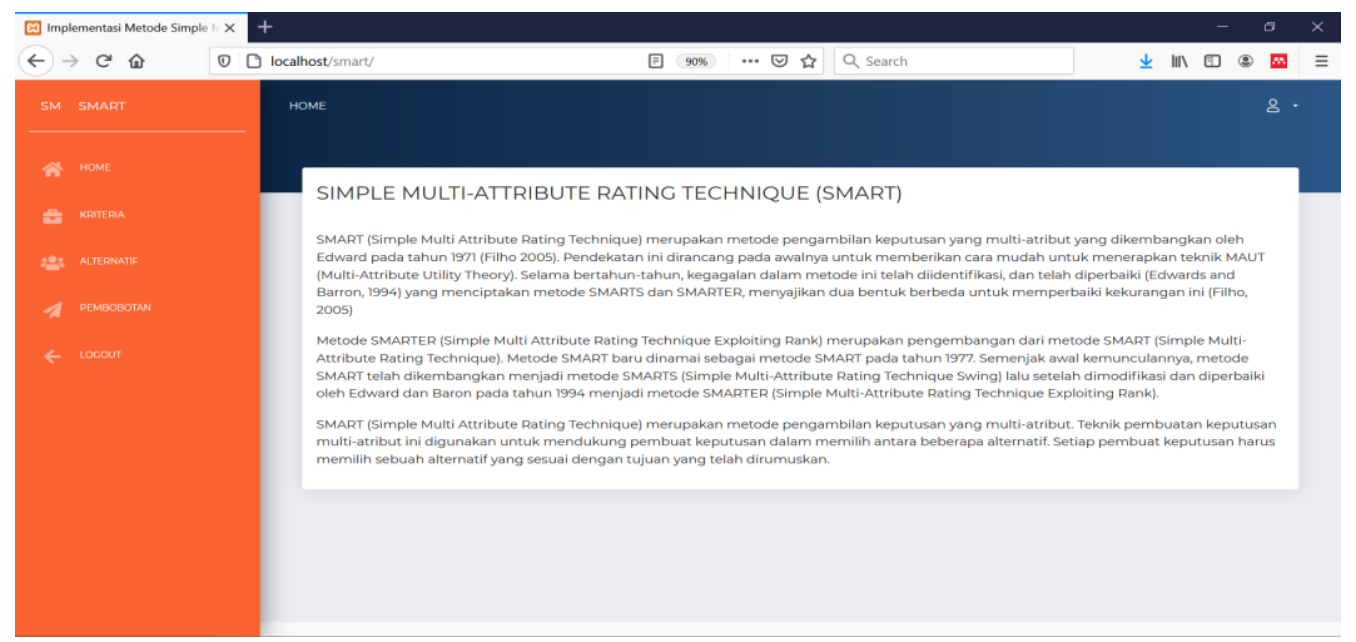

Gambar 7. Tampilan Menu Utama

\section{Tampilan Menu Kriteria}

Tampilan menu kriteria menampilkan kriteria yang dijadikan sebagai acuan dalam penyelesaian masalah. Adapun bentuk tampilannya seperti gambar 8 sebagai berikut :

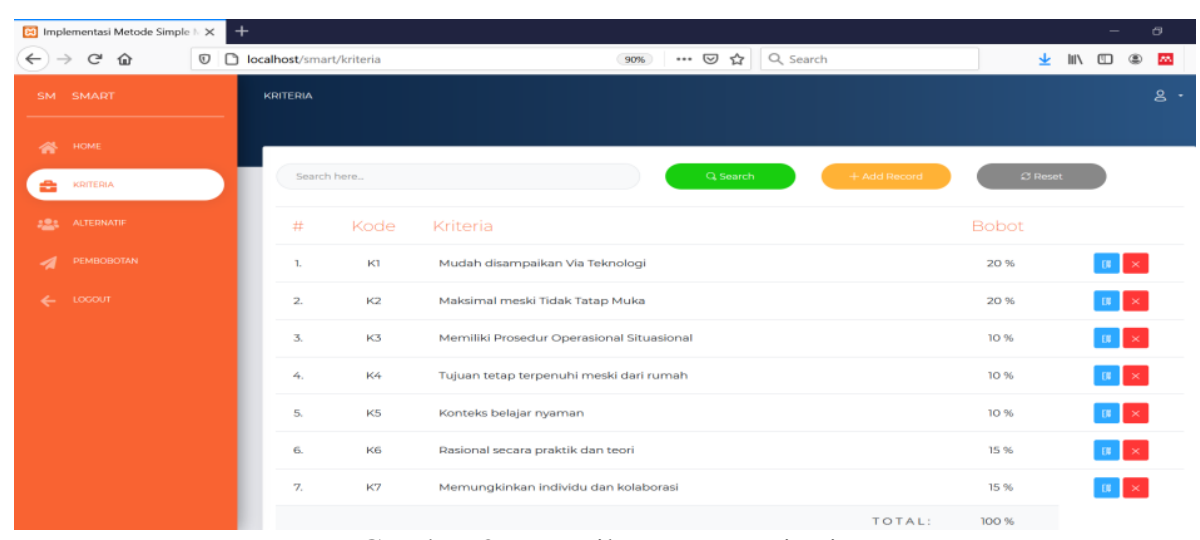

Gambar 8. Tampilan Menu Kriteria 
4. Tampilan Menu Alternatif

Tampilan menu alternative berisi alternatif model pembelajaran yang dijadikan data sampel atau komponen yang akan dipilih. Adapun tampilan menu alternatif seperti gambar 9 sebagai berikut :

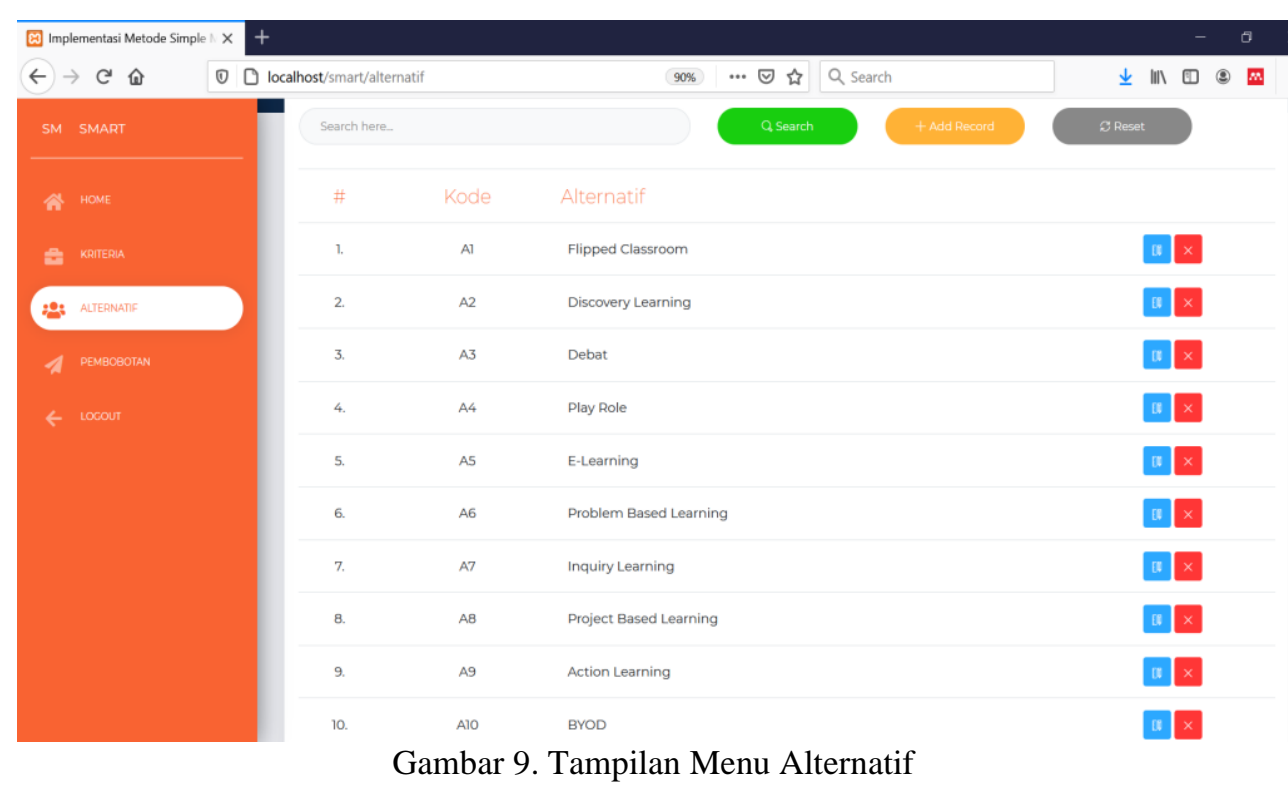

5. Tampilan Menu Perangkingan

Pada tampilan menu perangkingan didapatkan hasil perangkingan dari seluruh alternatif yang ada. Hasil perangkingan didapatkan setelah dilakukan pembobotan setiap alternatif sesuai dengan kriteria yang ada. Kemudian setiap pembobotan mendapatkan normalisasi berdasarkan kriteria yang ada. Adapun tampilannya seperti gambar 10 sebagai berikut :

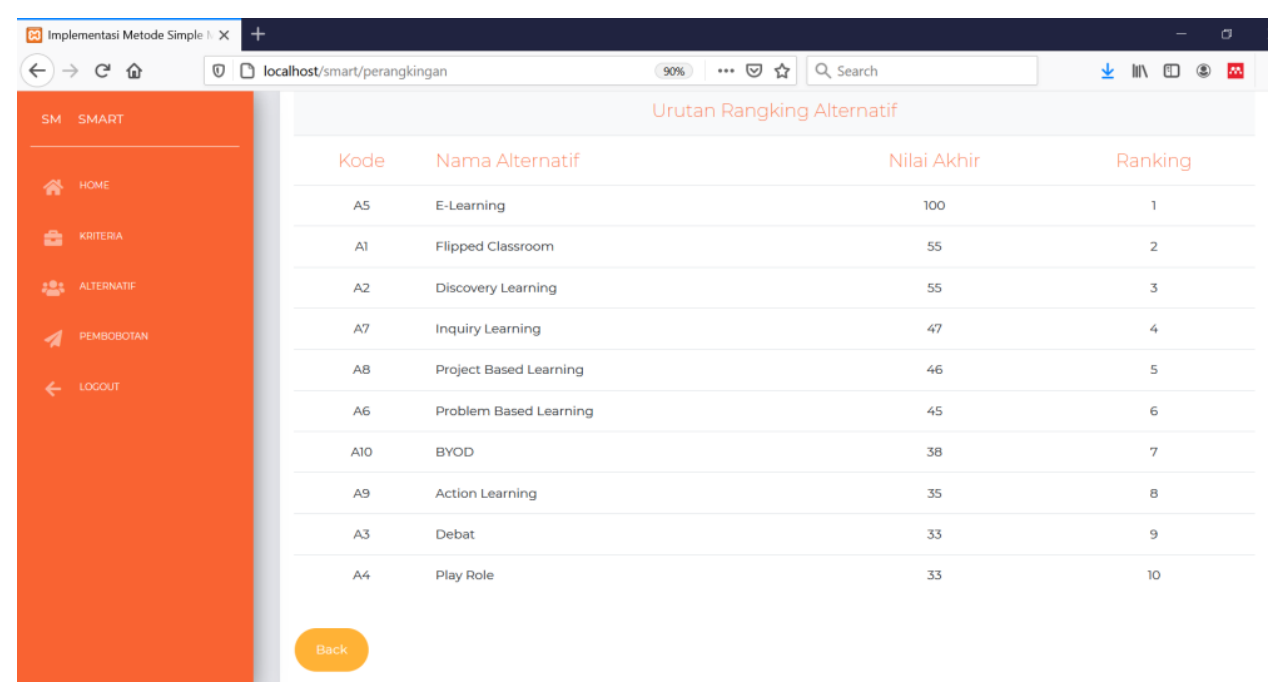

Gambar 10. Tampilan Menu Perangkingan

Dari tampilan di gambar 10 terlihat bahwa E-Learning mendapatkan rangking paling tinggi berdasarkan kriteria dan pembobotan yang dilakukan. Dengan demikian dapat disimpulkan bahwa E-Learning merupakan model pembelajaran yang sangat tepat dipilih sebagai model pembelajaran di masa pandemi Covid-19. Sehingga solusi dari permasalahan yang dihadapi yakni dengan menggunakan model pembelajaran E-Learning. 


\subsection{Pengujian Penerimaan Sistem}

Pengujian penerimaan dari sistem yang telah dirancang kemudian dibangun dengan menggunakan bahasa pemrograman berbasis website, dilakukan untuk mengetahui sejauh mana sistem yang dibangun dapat dipergunakan dengan maksimal oleh pengguna. Sehingga dapat diketahui seperti apa kebermanfaatan dari sistem yang dibangun dan tingkatan kemudahan penggunaanya. Adapun sistem pengujian yang dilakukan yakni dengan memberikan akses kepada pengguna untuk langsung menggunakan sistem yang telah dibangun. Setelah menggunakan, pengguna diminta untuk menjawab pertanyaan-pertanyaan yang telah disiapkan dalam beberapa lembar kertas. Adapun bentuk aspek dan indikator berikut nomor soal dan jumlah, seperti tabel 10 berikut :

Tabel 10 Bentuk Aspek dan Indikator Pengujian

\begin{tabular}{|c|c|c|c|}
\hline Aspek & Indikator & Nomor Pertanyaan & Jumlah \\
\hline \multirow{3}{*}{ Penggunaan } & Kesesuaiaan Kegunaan & $1-8$ & 8 \\
\cline { 2 - 4 } & Kemudahan Penggunaan & $9-19$ & 11 \\
\cline { 2 - 4 } & Mudah dipelajari & $20-23$ & 4 \\
\cline { 2 - 4 } & Kepuasan Menggunakan & $24-30$ & 7 \\
\hline \multicolumn{3}{|c|}{ Jumlah Butir } & 30 \\
\hline
\end{tabular}

Setelah menentukan aspek dan indikator pengujian, kemudian ditentukan pula kategori yang menjadi bagian dari data yang telah diolah untuk pengujian penerimaan sistem. Adapun kategorinya seperti pada tabel 11 dibawah :

Tabel 11 Bentuk Aspek dan Indikator Pengujian

\begin{tabular}{|c|c|c|}
\hline No & Presentase & Kategori \\
\hline 1. & $20 \%-36 \%$ & Sangat Tidak Layak \\
\hline 2. & $37 \%-52 \%$ & Tidak Layak \\
\hline 3. & $53 \%-68 \%$ & Kurang Layak \\
\hline 4. & $69 \%-84 \%$ & Layak \\
\hline 5 & $85 \%-100 \%$ & Sangat Layak \\
\hline
\end{tabular}

Kemudian dilakukan pengujian terhadap sistem yang telah dibangun. Pengujian dilakukan oleh 62 orang dengan langsung menggunakan sistem yang telah dibangun mengacu kepada tahapan-tahapan penyelesaian dengan metode SMART. Setelah menggunakan sistem, pengguna diminta untuk mengisi pertanyaan-pertanyaan yang telah disiapkan. Berikut hasil datanya seperti tabel 12 :

Tabel 12 Bentuk Aspek dan Indikator Pengujian

\begin{tabular}{|c|c|c|c|c|c|}
\hline No & Aspek & Jumlah & Nilai Ideal & Jumlah Nilai & $\begin{array}{c}\text { Rata-rata Nilai } \\
(\%)\end{array}$ \\
\hline 1. & Kesesuaiaan Kegunaan & 8 & 2480 & 2056 & 82,90 \\
\hline 2. & Kemudahan Penggunaan & 11 & 3410 & 2733 & 80,15 \\
\hline 3. & Mudah dipelajari & 4 & 1240 & 1007 & 81,21 \\
\hline 4. & Kepuasan Menggunakan & 7 & 2170 & 1788 & 82,40 \\
\hline & Total & 30 & 9300 & 7584 & 81,55 \\
\hline
\end{tabular}

Berdasarkan tabel 12 diatas dapat diperoleh kesimpulan bahwa hasil dari pengujian sistem yang langsung dilakukan oleh pengguna menghasilkan Kesesuaiaan Kegunaan 82,90\% (Layak), Kemudahan Penggunaan 80,15\% (Layak), Mudah dipelajari 81,21\% (Layak), dan Kepuasan Menggunakan 82,40\% (Layak). Keseluruhan pengguna secara jelas menyatakan bahwa sistem yang telah dibangun layak untuk dipergunakan. Dapat digambarkan dalam bentuk grafik pada gambar 11 sebagai berikut : 


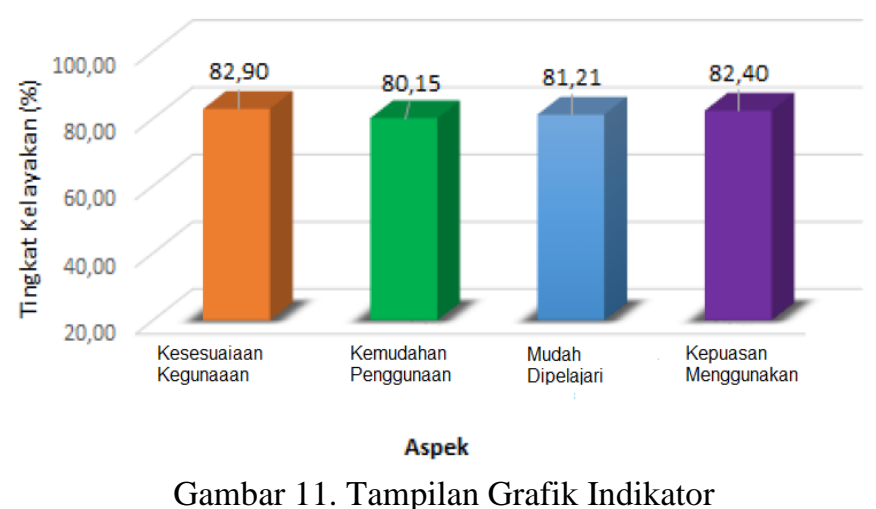

4. KESIMPULAN DAN SARAN

Adapun yang menjadi kesimpulan yakni metode Simple Multi Attributerating Technique (SMART) dapat dipergunakan untuk memilih model pembelajaran yang tepat dan baik dipergunakan pada masa pandemi Covid-19. Dimana langkah-langkah penyelesaian dengan metode Simple Multi Attributerating Technique (SMART) dapat menjadikan proses penyelesaian berjalan dengan cepat dengan tingkat akurasi yang baik. Hal ini terlihat dari hasil pengujian Kesesuaiaan Kegunaan 82,90\% (Layak), Kemudahan Penggunaan 80,15\% (Layak), Mudah dipelajari 81,21\% (Layak), dan Kepuasan Menggunakan 82,40\% (Layak). Kombinasi antara metode Simple Multi Attributerating Technique (SMART) dengan bahasa pemrograman berbasis website dalam hal ini PHP dan database berbasis server MySQL juga berjalan dengan baik. Terbukti penyelesaian dengan menggunakan sistem yang dibangun juga berjalan dengan baik dan menghasilkan E-Learning sebagai model pembelajaran yang tepat dipergunakan pada masa pandemi Covid-19.

\section{DAFTAR PUSTAKA}

[1] R. A. Purba, "Kampus Merdeka Dalam New Normal: Risiko Dan Kesempatan," Kampus Merdeka Seri 3 Mengen. Risiko Sist. Kampus Merdeka di Masa New Norm., p. 95.

[2] U. Verawardina and J. Jama, "Philosophy TVET Di Era Derupsi Revolusi Industri 4.0 Di Indonesia," J. Filsafat Indones., vol. 1, no. 3, pp. 104-111, 2018.

[3] R. A. Purba, "Memprediksi Layanan Akademik Di Politeknik Unggul LP3M Menggunakan Jaringan Saraf Tiruan Backpropagation,” Sesindo 9, vol. 2017, 2017.

[4] R. A. Purba et al., Aplikasi Teknologi Informasi: Teori dan Implementasi. Yayasan Kita Menulis, 2020.

[5] P. Poningsih et al., Sistem Pendukung Keputusan: Penerapan dan 10 Contoh Studi Kasus. Yayasan Kita Menulis, 2020.

[6] A. P. W. G. R. Pangaribuan, W. P. Mustika, and A. Wanto, "Pemilihan Jenis Sapi bagi Peternak Sapi Potong dengan Metode SMART," Algoritm. J. Ilmu Komput. dan Inf., vol. 3, no. 1, pp. 30-37, 2019.

[7] T. Magrisa, K. D. K. Wardhani, and M. R. A. Saf, "Implementasi Metode SMART pada Sistem Pendukung Keputusan Pemilihan Kegiatan Ekstrakurikuler untuk Siswa SMA,” Inform. Mulawarman J. Ilm. Ilmu Komput., vol. 13, no. 1, pp. 49-55, 2018.

[8] S. Suryanto and M. Safrizal, "Sistem Pendukung Keputusan Pemilihan Karyawan Teladan denganMetode SMART (Simple Multi Attribute Rating Technique)," J. CoreIT J. Has. Penelit. Ilmu Komput. dan Teknol. Inf., vol. 1, no. 1, pp. 25-29, 2015.

[9] I. M. A. Santosa, "Perancangan Sistem Pendukung Keputusan Pemilihan Sekolah PAUD Menggunakan Metode SMART," E-Proceedings KNS\&I STIKOM Bali, pp. 446-451, 2017. 
[10] R. A. Purba et al., Teknologi Pendidikan. Yayasan Kita Menulis, 2020.

[11] A. P. R. Pinem, T. Handayani, and L. M. Huizen, "Comparison of the Electre, SMART and Aras Methods in Determining Priority for Post-Natural Disaster Renaksi Priorities," J. RESTI (Rekayasa Sist. Dan Teknol. Informasi), vol. 4, no. 1, pp. 109-116, 2020.

[12] M. W. L. Moreira, J. J. P. C. Rodrigues, V. Korotaev, J. Al-Muhtadi, and N. Kumar, "A Comprehensive Review on SMART Decision Support Systems For Health Care," IEEE Syst. J., vol. 13, no. 3, pp. 3536-3545, 2019.

[13] J. Kangas and A. Kangas, "Multiple Criteria Decision Support In Forest ManagementThe Approach, Methods Applied, and Experiences Gained," For. Ecol. Manage., vol. 207, no. 1-2, pp. 133-143, 2005. 